\title{
B-CON Course: Skills Acquired at Training in Bleeding Control Techniques for the Prevention of Exsanguinating Hemorrhage
}

\author{
Juan P Fernandez ${ }^{1}$, Ruben D Algieri ${ }^{2}$, Maria S Ferrante ${ }^{3}$, Carolina C Brofman ${ }^{4}$, Agustín D Algieri ${ }^{5}$
}

\begin{abstract}
Introduction: Bleeding is one of the main causes of death associated with trauma. In the general population, knowledge of techniques to control bleeding is scarce or null in most situations, as well as the tools needed to perform them. The American College of Surgeons (ACS) "Stop the Bleed" campaign has the objective of training nonmedical personnel to perform lifesaving maneuvers to control bleeding in emergency and trauma situations.

Materials and methods: A prospective, observational study. Surveys were conducted on knowledge of maneuvers to control bleeding among nonmedical personnel. The training was done using the "Stop the Bleeding" B-CON Course of the ACS followed by evaluations.

Results: Four hundred and twelve nonmedical military personnel were trained, of whom 320 were medical students 27 surgical assistants, 35 nursing assistants, and 30 members of the armed forces. 92.7\% (382) had no previous knowledge of any of the maneuvers. $73.3 \%$ (302) had some familiarity with tourniquets, of whom $6.55 \%$ (27) knew how to apply it. One hundred percent reported being unprepared to perform the maneuvers on their own before the course. Evaluation: after taking the course, 401 (92.3\%) were able to correctly place the tourniquet on others, while $223(54.1 \%)$ were able to apply on themselves. All participants (100\%) performed wound compression correctly. Three hundred and forty-one (82.7\%) reported feeling fully capable to perform the maneuvers after the course, while $71(17.2 \%)$ requested to repeat it. One hundred percent of the respondents reported that the acquired skills and knowledge were beneficial.

Conclusion: The training of nonmedical military personnel, as well as the general population, may be valuable to reduce deaths caused by exsanguinating hemorrhage. The authors believe educational programs are recommended and should be implemented in the general civilian and military communities as well as making the necessary tools widely available. The active participation of the medical community and their continuous interaction with the general population via injury prevention activities are important to reduce deaths caused by trauma.

Keywords: Bleeding control, Continuous training, Military trauma, Preventable deaths, Trauma.
\end{abstract}

\section{Resumen}

Introducción: La presencia de lesiones con riesgos de hemorragias exanguinantes es una de las causas principales de muerte asociada al trauma. El conocimiento de la población sobre técnicas para el control del sangrado es escasa o nula en la mayoría de las situaciones así como también los elementos necesarios para la realización de las mismas. El Colegio Americano de Cirujanos a través de su campaña "Stop the Bleed" propone como objetivo la capacitación del personal no medico para el aprendizaje de maniobras para el básico de las hemorragias en situaciones de emergencia y trauma.

Metodos: Estudio prospectivo, observacional. Se realizaron encuestas sobre conocimientos en maniobras de control hemorragias en personal no medico. Se realizo capacitación mediante Bleeding Control Course del ACS y se realizo evaluaciones posteriors.

Resultados: 412 personal no medico. 320 estudiantes 27 Instrumentadoras quirúrgicas, 35 auxiliares de enfermería y 30 miembros de Fuerzas Armadas. 92.7\% (382) desconocían las maniobras. 73.3\% (302) conocían el Torniquete. 6.55\% (27) sabia utilizarlo. 100\% refería no contar con los elementos necesarios.

Evaluación: 401 (92.3\%) pudieron colocar el torniquete correctamente, 223 (54.1\%) auto colocárselo. El 100\% realizo compresión de heridas correctamente. 341 (82.7\%) refirió sentirse capacitado posterior al curso y 71 (17.2\%) solicitaron repetirlo. El 100\% de los encuestados sugirió que los conocimientos adquiridos resultaron beneficiosos.

Conclusione: La capacitación del personal no medico así como el resto de la comunidad resulta fundamental para prevenir las complicaciones inherentes a las hemorragias exanguinantes. Los programas educativos deben ser implementadas en todas las instancias y organismos de la comunidad así como también la adquisición de dispositivos para tal fin. La participación activa de la comunidad medica y la interacción constante mediante medidas de prevención son una pieza fundamental para la disminución de las muertes generadas por este tipo de patologías.

Palabras clave: Capacitacion continua, Hemorrhage control, Muertes prevenibles, Trauma, Trauma military.

Panamerican Journal of Trauma, Critical Care \& Emergency Surgery (2020): 10.5005/jp-journals-10030-1302

\section{INTRODUCTION}

Bleeding is among the main causes of deaths due to trauma. In Argentina and across Latin America, interpersonal violence and the growing number of road traffic injuries led to many preventable deaths reaching epidemic proportions, and at enormous cost to the entire health systems. It is known that training the general

\footnotetext{
${ }^{1}$ Department of Cirugia General, Hospital Aeronautico Central, CABA, Buenos Aires, Argentina

${ }^{2,3}$ Department of Cirugía, Hospital Aeronáutico Central, Ciudad de Buenos Aires, Argentina

${ }^{4}$ Department of Emergencias, Hospital Aeronautico Central, CABA, Argentina
} 
population on techniques to control bleeding is virtually nonexistent and the tools necessary to perform them are rarely available, even inside hospitals and military institutions where many are at risk of dying from bleeding. Faced with these challenges, the American College of Surgeons (ACS) proposed mass training using the "Stop the Bleed" course and campaign, to educate nonmedical personnel on the basic maneuvers to control hemorrhage in emergency and trauma situations. The course has been broadly accepted. Furthermore, it has trained a large number of professionals that may function as instructors and thus extending the reach to an even larger number of people.

The objective of the present study was to analyze skills and knowledge acquisition by nonmedical military personnel from the Argentina Armed Forces after taking the B-CON Stop the Bleeding course.

\section{Materials and Methods}

This is a prospective, observational study. Training on bleeding control principles was taught to nonmedical military personnel, members of the Argentina Armed and Security Forces and Medical students. The training consisted of the "Stop the Bleeding" B-CON Course of the ACS followed by a written examination and questionnaire evaluations, to measure knowledge and opinions of the course.

\section{Results}

A total of 412 nonmedical people took the course and performed the surveys. It included 320 students, 27 operating room surgical assistants, 35 nursing assistants, and 30 members of the armed forces (Figs 1 to 4). The results indicated that 92.7\% (382) had no previous knowledge of the basic maneuvers of bleeding control. $73.3 \%$ (302) had some familiarity with tourniquets but only $6.55 \%$ (27) knew how to apply it properly and effectively. Notably, $100 \%$ of the participants reported having no access to the tools necessary to carry out bleeding control maneuvers at their daily places of living, working, and studying.

The post-course evaluation revealed done immediately after completing the course, that $401(92.3 \%)$ were able to correctly place the tourniquet on others while 223 (54.1\%) could correctly self-apply the tourniquet (Fig. 5).

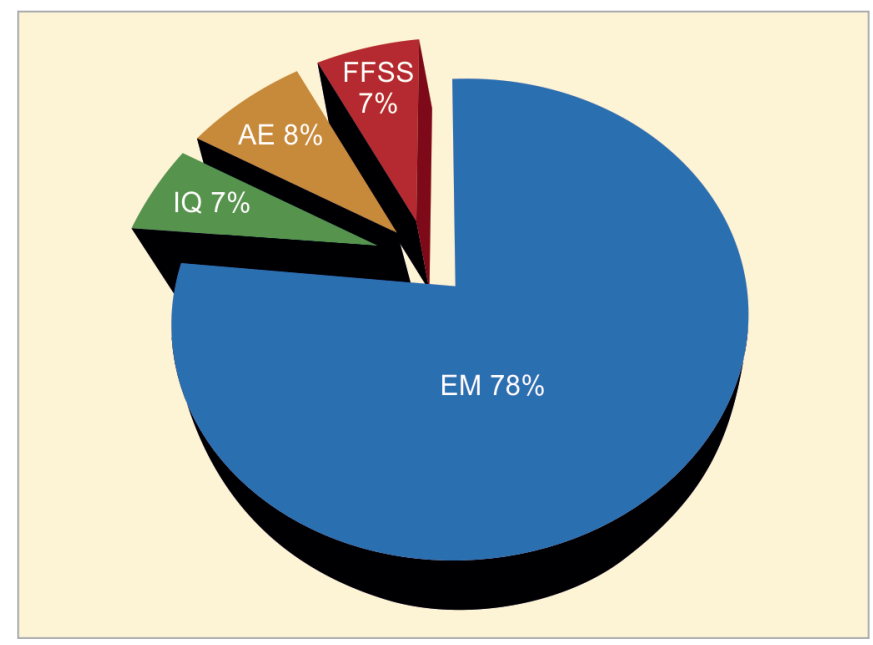

Fig. 1: Classification according to the level of training
${ }^{5}$ Catedra de Anatomía, Facultad de medicina, Universidad de buenos aires, CABA, bs as, Argentina

Corresponding Author: Ruben D Algieri, Department of Cirugía, Hospital Aeronáutico Central, Ciudad de Buenos Aires, Argentina, Phone: +5491152620505, e-mail: rdalgieri08@hotmail.com

How to cite this article: Fernandez JP, Algieri RD, Ferrante MS, et al. B-CON Course: Skills Acquired at Training in Bleeding Control Techniques for the Prevention of Exsanguinating Hemorrhage. Panam J Trauma Crit Care Emerg Surg 2020;9(3):209-212.

Source of support: Nil

Conflict of interest: None

The control of exsanguinating hemorrhages by direct wound compression was correctly done by all participants (100\%). Wound compression was the most acknowledged maneuver by all participants, which reported it to be easy to perform and reproduce. Regarding course contents and teaching methodology, $341(82.7 \%)$ reported feeling empowered by the course, and 71 (17.2\%) requested to repeat it to further solidify the learning (Fig. 6). One hundred of the respondents recognized that the knowledge acquired was beneficial.

\section{Discussion}

The likelihood of dying due to traumatic exsanguinating injuries is inversely proportional to the wealth and human development of the country, resulting in urgency to train the communities of Latin America, including civilians, military, and non-health citizens, on how to control bleeding. ${ }^{1-4}$

It has been shown that primary maneuvers to control hemorrhage are easily taught and training can be done using established programs such as the "Stop de Bleed" B-CON course of the ACS. This course has hands-on activities, simulation, and repetitive sessions teaching technical maneuvers such as wound packing and the use of tourniquets for extremities..$^{3,5-7}$ Considering the simplicity of the skills, the course can be taught in virtually any educational institutions and too much of the general population, similar to the existing cardiopulmonary resuscitation (CPR) courses and the availability of DEA in schools, gyms, airports, sports institutions, etc. ${ }^{4,7-9}$

Different studies have shown that the use of teaching strategies on control maneuvers of exsanguinating hemorrhage can be taught

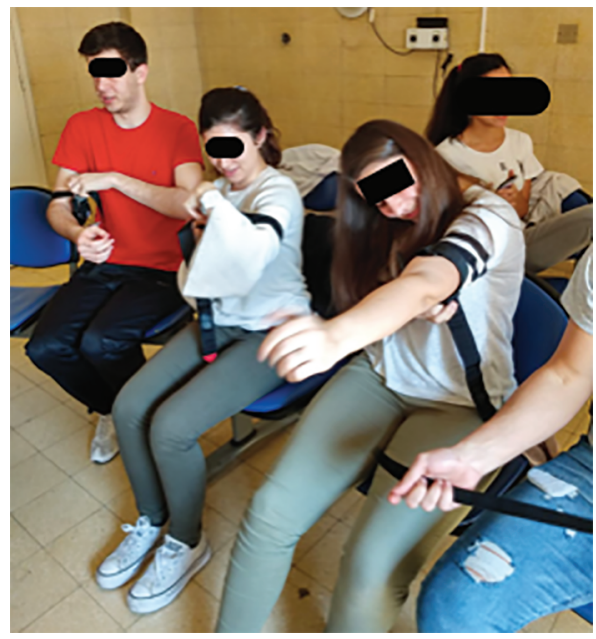

Fig. 2: Training medical students 


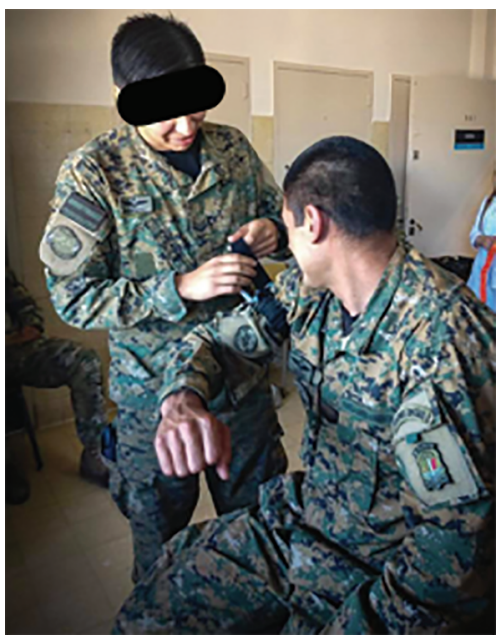

Fig. 3: Training military personnel

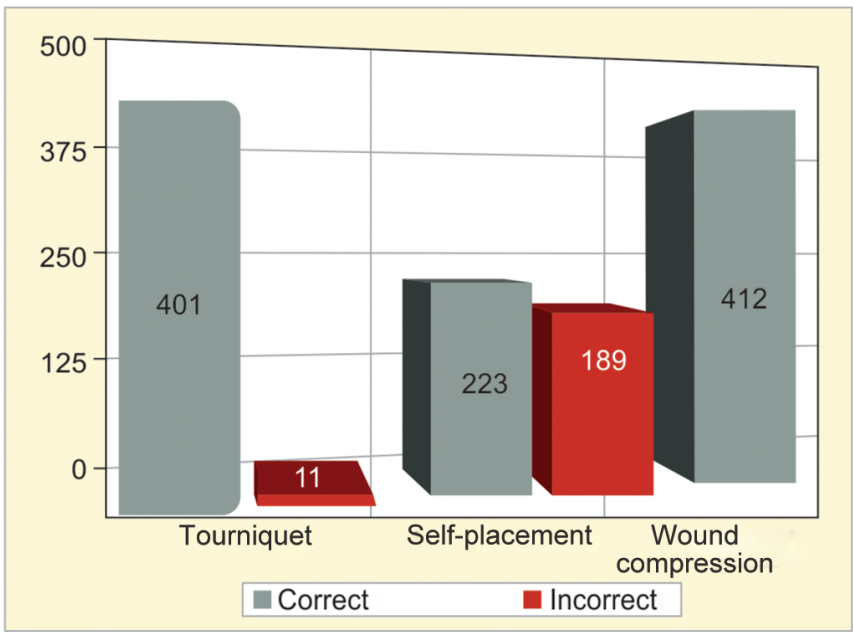

Fig. 5: Post-course evaluation

in school-age people with broad acceptance while for those with higher education (health professionals), teaching can use cadaveric models for simulation, which allows for greater realism for military personnel and security forces who must act as first responders in disaster situations and conflicts. $2,6,7,10,11$ Indeed, the international literature suggests that educating the greatest number of people would reduce mortality caused by hemorrhage, requiring for this purpose, the permanent commitment of the institutions and health authorities to disseminate, finance, and provide the necessary tools for the maneuvers to be correctly applied..$^{2,4,5}$

\section{Conclusion}

The authors believe that training nonmedical personnel as well as the general population could prove essential in preventing complications, including death, caused by hemorrhage. Educational programs should be implemented in all levels of society using community organizations as well as making the necessary tools such as tourniquets, widely available.

The active participation of the medical community and constant interaction through prevention measures are fundamental pieces to reduce deaths caused by trauma.
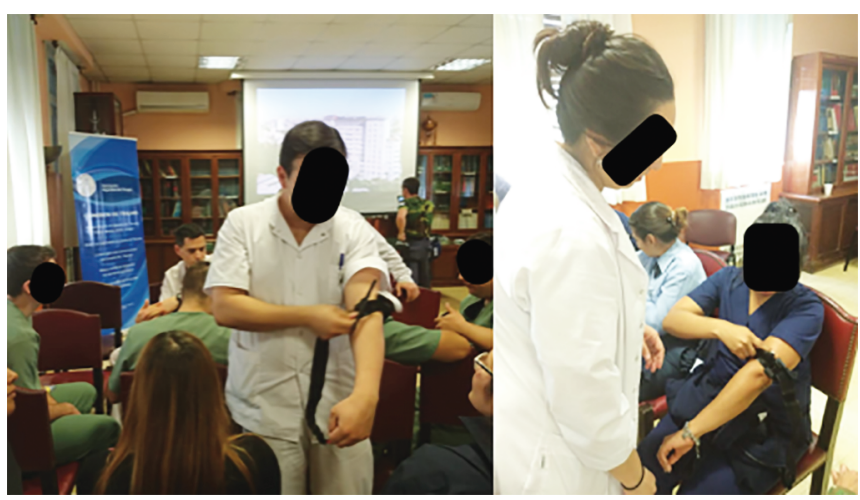

Fig. 4: Training health professionals

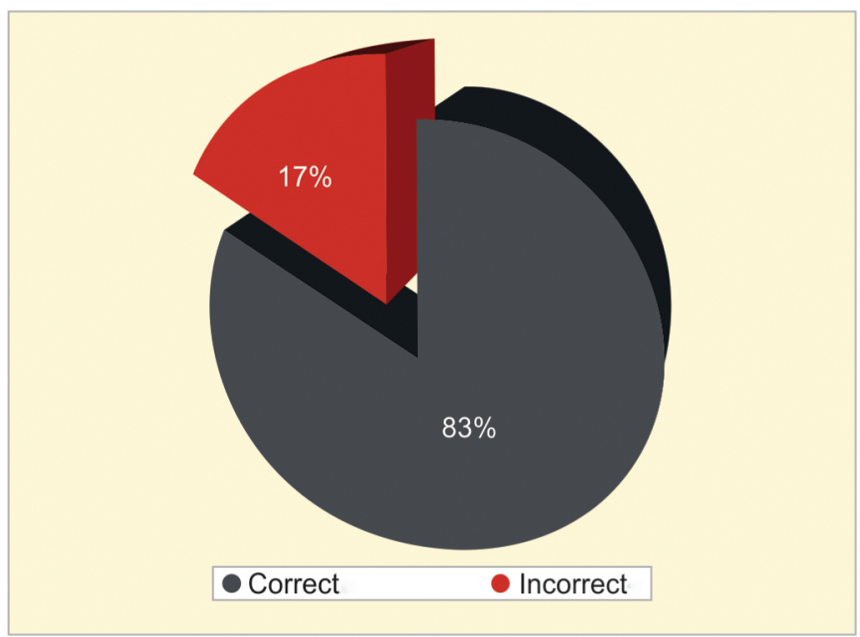

Fig. 6: Satisfaction with acquired knowledge (correct, repeat the course)

\section{References}

1. American College of Surgeons. Bleeding Control Basic (BCon) Course v. 1.0.- BleedingControl.org. 2018. Fecha de consulta: 16 de enero de 2017. Disponible en: https:// www.bleedingcontrol.org/private/ materials.

2. Berwick D, Downey A, Cornett E, ed., A National Trauma Care System: Integrating Military and Civilian Trauma Systems to Achieve Zero Preventable Deaths After Injury. Washington, DC: National Academies Press; 2016.

3. Goolsby C, Jacobs L, Hunt RC, et al. Stop the bleed education consortium. J Trauma Acute Care Surg 2018;84(1):205-210. DOI: 10.1097/TA.0000000000001732.

4. Wild J, Maher J, Frazee RC, et al. The fort hood massacre: lessons learned from a high profile mass casualty. J Trauma Acute Care Surg 2012;72(6):1709. DOI: 10.1097/TA.0b013e318250cd10.

5. Bulger EM, Gestring ML, Jacobs LM. Optimizing bleeding control training for the public: a national imperative. JAMA Surg 2018;153(9):799. DOI: 799. 10.1001/ja-masurg.2018.1100.

6. John Grabo Jr D, Polk T, Strumwasser A, et al. Demetrios demetriades a novel, perfused-cadaver simulation model for tourniquet training in military medics. J Spec Oper Med 2018;18(4):97-102.

7. Rasmussen TE, Baer DG, Goolsby C. The giving back: battlefield lesson to national preparedness. J Trauma Acute Care Surg 2016;80(1):166167. DOI: 10.1097/TA.0000000000000899.

8. Cummins RO, Ornato JP, Thies WH, et al. Improving survival from sudden cardiac arrest: the "chain of survival" concept. a statement for health professionals from the advanced cardiac life support 
subcommittee and the emergency cardiac care committee, American Heart Association. Circulation. 1991;83(5):1832-1847.

9. Einspruch EL, Lynch B, Aufderheide TP, et al. Retention of CPR skills learned in a traditional AHA Heartsaver course versus 30-min video self-training: a controlled randomized study. Resuscitation 2007;74(3):476-486. DOI: 10.1016/j.resuscitation.2007. 01.030 .
10. Eastridge BJ, Mabry RL, Seguin P, et al. Death on the battlefield (2001-2011): implications for the future of combat casualty care. J Trauma Acute Care Surg 2012;73:S431-S437. DOI: 10.1097/ TA.0b013e3182755dcc.

11. Kragh JF, Walters TJ, Baer DG, et al. Practical use of emergency tourniquets to stop bleeding in major limb trauma. J Trauma 2008;64(Supplement):S38-S50. DOI: 10.1097/TA.0b013e31816086b1. 